\title{
CONSUMERS APPRAISE THE FOOD, DRUG, AND COSMETIC ACT
}

\author{
Louige G. BALDWIN* aNd Florence KirLin†
}

"A long step forward," "an improvement over the 1906 law," "imperfect but perfectable," "a great advance in the definition of adulterated and misbranded foods and drugs," "inclusion of cosmetics, no matter how weakly, a great triumph," are some of the phrases heard in appraisal of the Food, Drug and Cosmetic Act of r938, and are expressive of the attitude of the national women's organizations ${ }^{1}$ that have been most closely identified with support of this type of legislation.

Because of the nature of the opposition to the bill, building up public support for sound legislation in the field became primarily the responsibility of these organizations. Only two national organizations were prepared to take action on the original bill, the American Home Economics Association and the National Congress of Parents and Teachers. Interest among women grew rapidly until the sixteen national organizations named were finally working for sound legislation.

These organizations, through their Washington representatives, were effective in the initial stages of drafting each bill. They gradually spread understanding of and support for the bill in the Congress by quiet, steady lobbying. They were represented at each hearing. They helped maintain the interest of the Administration in the legislation. Probably of greater significance was the educational work done among members of the organizations throughout the United States. There was never any doubt of the desire of their members for the protection and information sought by the legislation, but the extremely technical nature of the measure tended to thwart effective expression. The study groups, public meetings, tours of inspection, projects, and other educational devices used were legion. Large numbers of women learned

- B.S., I9I8, Teacher's College, Columbia University. First Vice President in charge of legislation, National League of Women Voters. 'Formerly Living Costs Chairmąn, National League of Women Voters; Extension work, United States Department of Agriculture.

† B.S., M.A., Indiana University. Congressional Secretary, National League of Women Voters, since 1934. Formerly Executive and Legislative Secretary Indiana League of Women Voters.

${ }^{1}$ Organizations that worked together in support of the Food; Drug and Cosmetic Act through the medium of the Women's Joint Congressional Committee were: American Ass'n of University Women, Women's National Homeopathic Medical Fraternity, National Council of Jewish Women, National Consumers League, National Congress of Parents \& Teachers, National Board of the Y. W. C. A., Girls Friendly Society of U. S. of America, Council of Women for Home Missions, American Nurses Asso. ciation, American Medical Women's Association, American Home Economics Association, American Dietetic Association, National Women's Trade Union League, National League of Women Voters.

The General Federation of Women's Clubs and the Women's Christian Temperance Union also were on record in support of this type of legislation. 
through their own investigations in their own communities of specific examples of the great need for the legislation. They gradually became so familiar with the technical details of the bill that such phrases as "multiple seizures," "jurisdictional amendment," "variation clause," "judicial review" rolled easily and convincingly from their tongues and pens. During the last two years none of these organizations supported any bill in its entirety, but persistently worked for strengthening amendments and agreed that the bill as passed was worth the effort it had cost.

The history of the legislation as reported in other articles in this publication indicates the numerous compromises that were made. Whenever the substantive provisions of the bill seemed to be approaching the ideals set by consumers, the attack would shift to the enforcement or procedural portions of the bill, and amendments would be made which would have nullified the effectiveness of the substantive provisions. Supporters of the legislation were constantly having to balance gains against losses and attempt to judge whether the result was a net gain or a net loss. The bill as finally passed did, in the opinion of the groups that had worked together in support of the legislation, represent a much greater improvement in the protection of consumer interests than had been thought possible during the two years prior to its final enactment.

Groups representing the consumer or public interest in this legislation were concerned $(I)$ that it require that adequate information about these products be made available to the purchaser, in order that intelligent choices might be made, and (2) that certain products injurious to the health or purse of the consumer be denied the market place. Because no law is better than its administration these groups also worked for sound administrative procedures and enforcement machinery.

\section{CONSUMER INFORMatton}

"Informative labeling" was a rallying cry for consumers. To the consumer informative labeling meant much more than that the label simply be not false. It meant disclosure of ingredients on the label of foods, drugs, devices and cosmetics and the amount of each ingredient; it meant adequate directions for use; it meant warnings against possible misuse of the product. The new act goes a long way toward this objective.

Adequate directions for use, warnings against misuse and of possible deterioration are required by the new law on drug labels. Also label declaration of drugs likely to be habit forming is provided. In the use of drugs it is essential that the individual know what the product is. If it is a drug for which no standard has been established, a proprietary product, the ingredients and the amount of each should be disclosed. However, under the new law, while active ingredients of non-standard drugs must be listed, no special order is required and the quantities need be stated only in the case of certain specified drugs which may be habit forming or otherwise dangerous. If it is an official drug for which a formula has been established and accepted it is important to know whether the drug in question meets the standard. If it varies from the standard in strength, quality or purity, it is important to know just how it 
varies. The so-called drug variation clause in the new act was one of the major points of controversy and one on which the consumer groups refused to yield. The new law permits variation from the accepted standard but requires that the label of the drug indicate exactly how it differs. This will give needed information to the layman in the use of household remedies, to physicians and pharmacists in the filling and use of prescriptions.

One of the labeling provisions requested by consumers, but not included in the law, was the listing of ingredients of cosmetics. This request on the part of the users of cosmetics was not prompted by a desire to learn the secrets of the manufacturers but to enable them to have a basis for judging the intrinsic value of the product and to avoid those products containing ingredients to which they might have allergic reactions. For example, a woman known to the writers of this article, is violently allergic to flax seed, an ingredient common in wave-set lotions. Neither the customer nor the operator could know whether the lotion used in the beauty shop contained this injurious ingredient and so she suffered several extremely painful experiences. In order to avoid these attacks, she now carries with her a flax-seed-less preparation.

The role of the twentieth-century housewife is quite different from the one of a hundred years ago who produced or knew the source of production of the goods necessary to maintain her household. Today, due to the ingeniousness of men and rapid strides in industry she is becoming less and less a producer and more and more a buyer with the world as her market. Despite the fact that now her table often looks like an international feast, the standard and quality of foods present themselves as a grave problem. As a rule her facility for acquiring information is limited; she has no laboratory at her disposal and is not a chemist; she cannot see through tin cans or card board packages. Therefore, in certain fields, she wants government to make certain decisions for her and to let her know what these decisions are. For this reason representatives of women's organizations sought to have written into law provisions for quality labeling of foods. Instead the law only provides for the establishment of a standard of identity and a single standard of quality, but even this will give a great deal more assistance to the buyer than was available prior to passage of the act and is a step toward the establishment of quality labeling. The Food and Drug Administration through a Food Standards Committee has already started on the long road toward establishing these minimum standards. One has only to think of the wide variety of products affected and the number of factors regarding each product which must be considered in arriving at a standard to realize the magnitude of the task.

In the case of those foods for which standards will not be established, and which are composed of more than one ingredient, the law requires that the principal ingredients be listed on the label, but the amount of each need not be indicated. Here a first step has been taken toward giving to consumers the information to which they are entitled.

The housewife also wants to be assured that products which are artificially colored are safe for use. The new law provides for government certification of coal- 
tar colors used in foods, drugs, and cosmetics with the exception of those used in hair-dyes. At the Food and Drug Administration, the new cosmetic division is undertaking as one of its first tasks the analysis of these coal-tar colors, a small part of the act but a tremendous undertaking. For instance, approximately fourteen hundred different shades are used in cosmetics, alone. Some 90 to roo separate colors are claimed by the industry to be essential. These colors must be tested to see if they are harmful if applied to the skin; if they should inadvertently get into one's eyes; if they are taken internally; if they are used over a long period of time.

It is to be regretted that hair-dyes are exempted from the regulations applying to other cosmetics in which coal-tar products are used. The application of a dye to hair with its varying reactions on different types of skin, is at best a gamble, but has been somewhat safeguarded under the new act by the label requirement. Each hairdye containing a coal-tar color must bear a warning against use of the product on eye-lashes or brows, and against any use without a preliminary skin test to determine the possible reaction on the individual. The effectiveness of this label requirement will depend entirely upon the fidelity with which the instructions are followed by the individual or beauty shop operator using the product. This exemption of hair-dyes containing poisonous coal-tar colors was evidently a compromise necessary to prevent serious weakening of the whole cosmetic section of the bill.

\section{Prohibitions Against Adulteration and Deception}

A large portion of the Food, Drug, and Cosmetic Act might be termed negative in that it prohibits certain acts but these prohibitions are certainly positive in their protection of the public interest. The buying public wants protection to its pocketbook as well as to health. It therefore welcomes those protections which come from outright prohibitions against certain practices which result in unclean or contaminated products or deception of the consumer through use of tricky containers and special treatment of products to make them seem better than they are. Prohibition of products dangerous to health seems a minimum safeguard to be offered by government.

Casual reading of the periodic announcements of judgments rendered by the courts at the instigation of the Food and Drug Administration shows vividly the need for such prohibitions. Unceasing watchfulness on the part of the Food and Drug Administration has helped protect the public from moldly butter, maggotty fruit, putrid fish, unclean foods and to protect ethical business from unfair competition. The new law has materially strengthened the hand of the Food and Drug Administration in giving the public "protection in this field. Two notable additions are the power granted to control added poisons in foods by regulation and the emergency permit control of food that may be injurious because of contamination with micro-organisms. The development of the fruit growing industry has necessitated the widespread use of lead-arsenate sprays to insure a marketable product; some of this poisonous spray remains on the fruit. Even good manufacturing practices cannot prevent some incidental contamination of other food products. In these 
instances, the new law requires that the public be safeguarded through the requirement that the administration set tolerances which will not be injurious, thus insuring minimum protection to the consumer. For the first time, the administration will be able to prevent the entrance of products into interstate commerce which may be injurious because of contamination with micro-organisms rather than waiting until the product is available for sale in interstate commerce and the lives of innumerable people endangered.

\section{Extension to New Fields and Elimination of Jokers}

Like other products cosmetics which were once made in the home are now to be found in great array on the counters in shops in even the smallest communities. Since the passage of the original food and drug law in 1906 the manufacture and sale of cosmetics has become one of the largest business enterprises in the country. While the present law does not provide for the listing of ingredients on the label of cosmetics it does for the first time bring them under government control and outlaws cosmetics which may be injurious to users. The necessity for such regulation has been demonstrated by numerous cases where cosmetics have defeated their purpose by robbing the users of both beauty and health. This latter provision went into effect immediately upon passage of the act and has already resulted in the removal from the market of certain eye-lash and brow dyes which were known to be dangerous. Members of womens organizations that supported this legislation remember with a shudder a member of one of their groups who was blinded from the use of an eyelash dye; also other cases of blindness from similar causes which occurred during the time the legislation was pending in Congress. It is comforting to know that at least for the moment such products have been removed from the market.

Extension of the act to cover drugs and devices intended to alter the structure or function of the body is another gain for consumers. Formerly products used for reducing purposes were not subject to the act and so such products as Marmola or preparations containing dinitriphenol could not be reached under the Food and Drug Act, no matter how harmful they might be proved to be.

A year ago the country was aghast over the death of some ninety persons as the result of taking a drug known as "Elixir Sulfanilamide." Due to the prompt action by the Food and Drug Administration the supply of this preparation was taken off the market. Since the 1906 Act contained no provision against dangerous drugs seizure had to be based on a charge of misbranding. Had the product been called a solution instead of an elixir the Food and Drug Administration would have been powerless to act. Two safeguards against a recurrence of such a tragedy exist in the new law. As a direct result of this tragedy the law prohibits traffic in new drugs unless they have been adequately tested to show that they are safe for use under the conditions of use prescribed in their labeling. Regulations defining the meaning of the term "new drugs" have been issued by the Secretary of Agriculture since 
that part of the law also went into effect immediately upon passage. The administration is also authorized to proceed against drugs and devices deemed to be dangerous to health, and warnings against such drugs as amidopyrine and cinchophen have already been issued.

Elimination of some of the jokers in the Igo6 law is one of the most important accomplishments of the new one. One of the most serious of these was the so-called fraud joker requiring the government to prove that not only did a drug manufacturer lie in his label statements but that he knew he lied. It is not easy to prove intent to deceive. Not only has this joker cost the taxpayers thousands of dollars while the government spent years in trying to prove its case, but thousands of people have suffered economically and physically from the use of worthless or actually harmful "cures." Under the new act the government needs only to prove that the claim of curative effect is false. The "distinctive name" proviso of the old law allowed foods fabricated from more than one ingredient to escape from the adulteration and misbranding provisions if they were sold under some fanciful name and were not actually poisonous. The housewife trying to get value received for her expenditures is glad that such disguise is not possible under the new act. It remains to be seen what new jokers will be discovered in the law when the courts have had opportunity to act on cases brought before them.

One of the important objectives of the proponents of this legislation was regulation of advertising of these products by the same agency having jurisdiction over label statements. Passage of the Wheeler-Lea bill giving specific powers to the Federal Trade Commission over advertising of food, drug and cosmetic products without giving to that agency truly effective enforcement machinery, was a serious disappointment. Once persons bought after reading the label, now the more general practice is to read the advertisement. The Food and Drug Administration could control more or less effectively statements made on the label, but practically anything could be said in the advertisement of the same product. Many a person took a proprietary medicine because the advertisement he read or listened to over the radio said it would cure disease (while the label said nothing, or merely that it would alleviate the disease). The manufacturer could not be prosecuted unless the label on the package was false and fraudulent or a complaint was filed with the Federal Trade Commission charging unfair competition. In the latter case, a long drawn out and ineffective procedure had to be followed under the terms of the organic act establishing the Federal Trade Commission. Proponents of the legislation contended vigorously from the first that advertising is simply an extension of the label and therefore should be subject to essentially the same kind of control by the same agency. The effectiveness of the Wheeler-Lea Act in protecting the public from false and misleading advertising of food, drug and cosmetic products will depend not only upon vigorous action by the Federal Trade Commission, but largely upon the awareness of the public and the cooperation of the industries. 


\section{The New Procedurat Provisions}

The possibility of making multiple seizures of adulterated and misbranded products was the principal reason for the effectiveness of the old law in spite of its many weaknesses. Because the new act eliminates many of these weaknesses the use of seizure has been restricted. It is thought that the limitation in the law conforms to the procedure followed by the Food and Drug Administration in enforcing the 1906 law, and therefore will not be a serious handicap. Some compromise had to be made in order to secure passage. It was the concern of citizen groups that such compromise not be one that would counteract the gains achieved in other parts of the law.

The provision for court review of regulations finally included in the law does seem to give a somewhat greater advantage to the industries affected than is ordinarily included in laws of this type. It is not however, so stringent in its effect on administration as to nullify the act. The court review section in the bill as it passed the House, would have so hampered enforcement that the groups concerned with the protection of the public were prepared to seek a presidential veto unless a satisfactory compromise was worked out in the conference committee.

Although these and a few other provisions may tend to weaken the enforcement machinery, increased penalties for violation, the use of injunction, and the improvement in the substantive provisions of the act seem to more than counteract any possible ill effect from these compromises.

\section{Conclusion}

Passage of a bill is not the end of citizen interest in it. It should be the beginning of a new responsibility, for to be effective a law needs sound administration and active citizen cooperation. The potentialities of the law under consideration here will be fully realized only if the consumer and the enforcing agency take full advantage of it. A great deal of the protection afforded consumers is in the information that will be given them in label declarations. If consumers do not read labels and fail to make their selection of purchases on the information given there, much of the value of the law will be lost. Continuing interest in promulgation of regulations is also an important responsibility of the consumer.

The Food and Drug Administration views the law as essentially a measure to protect the public and can probably be counted upon to the extent of its capacity to interpret the law in those instances requiring amplification by regulation to the advantage of the consumer. It has given remarkable service to the public in the past in spite of the handicaps of a deficient law and woefully inadequate appropriations. If Congress fails to increase the appropriations available for enforcement commensurate with the increased responsibilities under the act, the consumer will be penalized.

There are weaknesses in the law, unquestionably. How serious these are will only be determined after a period of enforcement. With the aroused interest of consumers, it should be possible to secure perfecting amendments as need becomes evident. 